\title{
From the Antecedents to the Purchase of Environmentally Friendly Products
}

\author{
Sinove MARDE \\ Associate Professor \\ University of Caen Normandy \\ IUT Cherbourg-Manche - Department GEA \\ 60, rue Max Pol Fouchet - 50130 \\ Cherbourg Octeville -France
}

\begin{abstract}
This research aims to provide a model that connects the antecedents of environmentally friendly consumption to two concrete variables that can be used as levers of action for companies, namely, the intention to purchase and the purchase. The antecedents are grouped into the following three constructs: "barriers to purchase"; "relations with the product" and "propensity to act" to protect the environment. A structural equation model is used to test whether the antecedents can predict the two action variables. The results show that the chosen antecedents are predictive indicators, but their degree of influence on the two endogenous variables differs. "Barriers to purchase" have a strong negative influence on intention and purchase, unlike "relations with the product", which positively but moderately influences intention and purchase. The "propensity to act" construct has a stronger influence on the intention to purchase than on the purchase.
\end{abstract}

Keywords: Antecedents of environmentally friendly consumption, intention to purchase, purchase

\section{Introduction}

Currently, protecting the environment has become a major issue for all stakeholders, specifically, firms, governments and consumers. At the state level, the actions being taken are more apparent, such as incentives to use more energyefficient lighting or the campaign against wasting food recently conducted in Europe. Additionally, the bilateral agreements concluded between the United States and China to reduce greenhouse gas emissions and with India in the field of renewable energy show that states undertake environmental advocacy. Concerning firms, some enhancements have been made, either because the firms are constrained or because they want to valorize their image. However, for consumers, the situation is more difficult to gauge. Consumer awareness certainly exists, but this awareness is not followed by subsequent concrete actions; therefore, a gap between positive attitudes and behaviours still remains (Carrington et al., 2010; Hassan et al., 2016). This gap particularly exists in the purchase of ecological products, which is one of the most important actions to reduce individual negative environmental consequences (Isenhour, 2010).

To address this situation, it is very important to better understand this purchasing process especially by identifying the drivers or barriers (Moser, 2015; Van Doorn and Verhoef, 2015) that would permit the adaptation of marketing strategies to environmentally friendly consumption. In this study, we adopt a broad definition of the ecological product proposed by Agence de l'Environnement et de la Maîtrise de l'Énergie-ADEME (2012). It is a product that "generates less impact on the environment throughout its life cycle: from the extraction of raw materials, to its manufacture, its transportation, its use and finally its end of life".

In the marketing literature, most research conducted in this field has answered the two central issues of who are ecological consumers and what are their reasons for purchasing? The answers to the first question allow researchers to observe some variables that characterize consumers buying eco-friendly products as sociodemographic characteristics (Diamantopoulos et al., 2003) or psychological variables. Investigations into the second question can detect which explanatory variables that capture buying behaviours are significant. If the responses to who are ecological consumers have sufficiently complete data to allow consumers to be targeted, the question of "why" requires further research because the reasons given by authors are often analysed separately (Basha and Lal, 2019; Paul and Rana, 2012) and we do not fully control their relative importance when they are measured as a whole.

However, in using some structural equation models for predicting green product purchase intention and behaviour, some analyses have led to encouraging results (Golob et al., 2018; Maniatis, 2016; Yadav and Pathak, 2016) that would be interesting to complete with other variables. 
Therefore, this research aims to provide a structural equation model that makes it possible to simultaneously integrate several antecedents of environmentally friendly consumption as explanatory variables and to test whether they can predict some operational variables. Like Laurent and Kapferer (1985), we use the concept of antecedents that in this paper, represents the determinants of a purchase. We think that it is essential to understand what occurs upstream of the purchasing process to take action on the final purchase. As a first step, the purpose is to identify the predictive indicators of a purchase by focusing on the antecedents. Because these antecedents are different not only in their nature but also in their intensity, it is very important to connect them to two key variables, the intention to purchase and the purchase, to detect which antecedents are the most predictive. The presence or absence of a causal association between them and the importance of their relationships will provide firms with some appropriate levers for action.

In the first part of this study, the theoretical framework is presented. Based on existing studies, we emphasise the antecedents of environmentally friendly consumption most frequently identified in the literature and explain why it is appropriate to use them. In the second part, a structural equation model that connects and measures these antecedents with the purchase and intention to purchase is proposed.

\section{Antecedents of environmentally friendly consumption}

\subsection{Why the interest in the antecedents of environmentally friendly consumption?}

According to Gleim et al. (2013), a green consumer represents "one that takes into account his or her impact on the physical environment when making product purchases". Consequently, "a green consumer purchases environmentally friendly products to minimize the potentially negative environmental impact of purchases". In this field, consumers use their buying power to express their environmental concerns. Therefore, the perceived consequences of their purchase such as a "decrease in pollution" and "forest conservation" are central. However, these environmental effects of purchases are insufficient to address this topic if we do not consider the cause of the purchase because the cause and effect are interdependent. For example, consumers change their behaviour and purchase green products to protect the environment because they are environmentally sensitive (Mostafa, 2007) or because the products are affordably priced.

Considering the antecedents allows a better understanding of consumer behaviours because it becomes possible to consider the global ecological consumption cycle, as recommended by Prothero et al. (2011). Once the antecedents have been identified, it becomes easier to understand the relations among them, their influence on the choice of an ecological product, and the perceived and desired consequences of the purchase. The antecedents may be used as variables for actions, and companies can rely on them to guide future behaviours, which have positive consequences on the environment.

Defining some consumption profiles for customers from the antecedents of consumption allows us to confront the limits of the current research. To propose profiles of green consumers, the authors use the act of purchasing, considering that the reasons observed at any given point in time will be renewed in the same way for future purchases. However, as Balderjahn (1988) notes, the acquisition process is specific to each product, and each purchase can be predicted by different variables. Therefore, to better understand the main aspects of environmentally friendly consumption, it is appropriate to build on its antecedents (Barbarossa and De Pelsmacker, 2016; Pagiaslis and Krontalis, 2014) and to measure their importance for each category of product.

Finally, predicting consumer behaviour by using several antecedents grouped into three constructs is more attractive for managers, as it makes it possible to know the reasons for purchase or non-purchase and their relative importance for each product and/or each consumer typology.

\subsection{The literature on the antecedents of environmentally friendly consumption}

There are various antecedents of environmentally friendly consumption. One stream of research in this field is based on the theory of planned behaviour (TPB - Ajzen, 1991), which is a suitable way to analyse these antecedents. In their recent study on the subject, Marde and Verite-Masserot (2018) propose some operational variables that are related to this theory (Table 1).

Tables 
Table 1. Operational variables related to the theory of planned behaviour

\begin{tabular}{|c|c|c|}
\hline $\begin{array}{l}\text { Theory of Planned Behaviour } \\
\text { (TPB - Ajzen, 1991) }\end{array}$ & $\begin{array}{l}\text { The variables related to the } \\
\text { components }\end{array}$ & $\begin{array}{l}\text { The variables used to } \\
\text { complete the component }\end{array}$ \\
\hline \multirow[b]{2}{*}{$\begin{array}{l}\text { Component 1: perceived } \\
\text { behavioural control }(\mathrm{PBC}),\end{array}$} & $\begin{array}{l}\text { Variables related to past } \\
\text { experience (relationship with } \\
\text { the product) } \\
\text { - Confidence } \\
\text { - Loyalty }\end{array}$ & $\begin{array}{ll}- & \text { Perceived consumer } \\
\text { effectiveness (PCE) } \\
\text { - } \quad \text { Values }\end{array}$ \\
\hline & $\begin{array}{l}\text { Variables related to the } \\
\text { barriers to purchase } \\
\text { - Difficulties in } \\
\text { finding the product } \\
\text { - Available } \\
\text { information } \\
\text { - } \text { Buying habits } \\
\text { - } \text { Price }\end{array}$ & \\
\hline $\begin{array}{l}\text { Component } 2: \quad \text { "subjective } \\
\text { norms" }\end{array}$ & - $\quad$ Social influence & \\
\hline Component 3: "attitude" & $\begin{array}{l}\text { Replaced in this study by the } \\
\text { concept of "concern" }\end{array}$ & \\
\hline
\end{tabular}

\section{Perceived behavioural control (PBC)}

One component of the TPB is perceived behavioural control (PBC), which refers "to the perceived ease or difficulties of performing behaviour; it is assumed to reflect past experience as well as anticipated impediments and obstacles" (Ajzen, 1987). To make PBC more operational, Marde and Verite-Masserot (2018) propose using variables that give accounts of past experiences, and they integrate different barriers such as situational, personal and economic variables (Stern, 1999). Among the situational variables are the perceived difficulties in finding the products and the available information. It is indeed important to consider these factors, as $75 \%$ of Europeans say that they are interested in green products, but the majority do not buy them for one of these reasons (European Commission, 2013). Concerning the personal barrier, one important obstacle is a "buying habit" for conventional products (Vermeir and Verbeke, 2006; Wiederhold and Martinez, 2018) that most people are not willing to change in favour of environmentally friendly products. The last variable of an economic nature is price, which is a barrier for many consumers given their budgets (Gilg et al., 2005).

Regarding the past experiences that determine the relationship that a consumer has with a product, two concepts are proposed by these authors. First, there is "confidence", which is a determining criterion for this type of product (Nuttavuthisit and Thøgersen, 2017; Vermeir and Verbeke, 2008); these products represent a purchase as committing to an environmental cause where consumers hope to buy products that keep their promises. The second concept is "loyalty", which reflects past successful experiences with the product and thus captures a strong affective relationship between the consumer and the product (Bozzo et al., 2003).

The notion of PBC suggests that the individual uses his or her previous experience to anticipate and thus avoid future difficulties. However, it does not integrate individuals' beliefs, which are important elements to consider in the decision-making process. In marketing, two psychological variables have been used in the studies of green buying behaviour, namely, "perceived consumer effectiveness" (PCE) (Albayrak et al., 2011; Kim and Choi, 2005; Straughan and Roberts, 1999) and "values" (Ghazali et al., 2017; Pickett-Baker and Ozaki, 2008). PCE represents the extent to which a consumer believes that personal effort can contribute to solving environmental problems (Ellen et al., 1991; Kinnear et al., 1974), whereas a value is "an enduring belief that a specific mode of conduct or end-state of existence is personally or socially preferable" Rokeach (1973).

\section{Subjective norms}


The second component of the TPB is "subjective norms", which is defined by Ajzen (1991) as the "perceived social pressure to perform or not perform the behaviour". In their study, Marde and Verite-Masserot (2018) show that the direct environment of the consumer, including friends and family, is a determinant, while the influence of the state and the media is not a determinant.

\section{Attitude}

To obtain the predictive antecedents of purchasing behaviour on which managers can act, the last component of the TBP, "attitude", has not been integrated as such by these authors. This can be effectively justified by several arguments. According to the founder of the TPB, the "attitude" component refers to the "degree to which a person has a favorable or unfavorable evaluation or appraisal of the behavior in question" (Ajzen, 1991), and if an attitude is positive, behavioural intentions tend to be more positive (Chen and Tung, 2014). In the domain of environmentally friendly consumption, several studies reveal this positive relationship between attitude and intention (Hsu et al., 2017; Paul et al., 2016), but the existing influence between these variables must be treated with caution. Indeed, in the TPB, attitude has a one-dimensional character: it is expressed by positive or negative affective responses. However, for other authors, attitude has a three-dimensional character (Ostrom, 1969; Rosenberg and Hovland, 1960): its evaluation is cognitive (knowledge and beliefs about the object of attitude), conative (intentions), and affective. In the first case, the conative component of attitude is then assimilated into the intention to purchase, which makes it a unique complete concept; this likely explains the positive relationship that often exists between these two variables. Another reason that attitude has not been integrated concerns social desirability bias regarding environmental problems. Often, the reading of the question that measures attitude could influence the respondents and cause a change in this belief or even generate a sense of guilt or responsibility that ultimately makes the behaviour desirable to the point of actually wanting to adopt it (Ogden, 2003) and to positively change attitudes. Finally, the high level of generality with which this construct is defined makes it possible to theoretically explain a wide range of psychological phenomena (Giger, 2008) but prevents the derivation of detailed hypotheses that are likely to be used to guide marketing strategies. Marde and VeriteMasserot (2018) prefer the notion of "environmental concern", which certainly denotes an individual's general orientation towards the environment (Kim and Choi, 2005) but can be measured by more committed items such as "I would describe myself as a person fighting on behalf of the environment".

In the following section, we propose testing the predictivity of the aforementioned antecedents. Therefore, a structural equation model that links them to the two action variables, intent and buying behaviour, is proposed.

\subsection{The relationship among the antecedents, purchase intention and environmentally friendly purchase}

The antecedents are grouped into three constructs (Marde and Verite-Masserot, 2018). The first construct is called "barriers to purchase" and includes the "price", "perceived difficulties", "purchasing habits" and "available information". The second construct, which represents the "relations with the product", comprises the two elements of "level of confidence in" and "loyalty". The last construct, named "propensity to act", includes "concern" for the environment, "perceived consumer effectiveness", "social influence" and "values".

From these constructs, a conceptual model is proposed (Appendix 1) that allows us to check in a single analysis the power and predictive intensity of each group of the antecedents on the intention to purchase and on the current purchase. It is important to consider these two variables because if the purchase intention is hypothetical and uncertain but nevertheless necessary in future projections, the current purchase makes it possible to obtain a more accurate indication of ecological behaviour (Moser, 2015).

In this study, we choose not to link purchase intention to current buying behaviour because it is not relevant. Intention is a future willingness to do something, while the current behaviour represents what a person is already doing. Moreover, we use a measure of current purchase as suggested by Andorfer and Liebe (2012), such as "what average budget do you spend on your purchase of ecological personal care products per week?" As such, the behaviour represents an event that has already occurred and thus cannot be a causal outcome of future intention.

The test of the proposed model should allow companies to know which antecedents are the most important. It is assumed that these antecedents have a direct effect on purchase intention and on the purchase, but several questions remain about these relations. Which constructs are the most influential?

Are these influences positive or negative? Do these three constructs have a greater effect on intent or purchase? These questions lead us to formulate three hypotheses concerning these constructs.

The first construct, "barriers to purchase", captures the barriers to individuals' actions in favour of environmentally friendly products. Many consumers say that they are interested in these products but do not buy them due to barriers 
(Robinson and Smith, 2002), which are represented in this study by four components. The following hypothesis is therefore considered:

H1: The construct of "barriers to purchase" negatively influences the purchase intention and purchase of environmentally friendly products.

In contrast, the "relations with the product" construct, which is represented by the "confidence" and "loyalty" dimensions, should have an inverse and positive effect on the endogenous variables because these two dimensions imply successful experiences with the products, which leads to repurchasing them. When making a purchase decision, the consumer does not consider the product in isolation: he interprets the new information by considering not only the purchasing context (Plous, 1993) but also his past experience with the product (Pickett- Baker and Ozaki, 2008). Given confidence or loyalty towards a product and generally a greater overall positive feeling for a product, a consumer is more inclined to purchase it. Therefore, hypothesis 2 is as follows:

H2: The construct "relations with the product" positively influences the purchase intention and purchase of environmentally friendly products.

The "propensity to act" construct, which also comprises four dimensions, refers to a general orientation of the consumer to act in favour of the environment. This construct ranges from a global concern for the environment to a personal belief that consumers can help to solve environmental problems (PCE), and consumers with this orientation are likely to have favourable attitudes and behaviours towards the purchase of environmentally friendly products. Regarding ecological values such as universalism or benevolence (Grunert and Juhl, 1995), once adopted, the values appear to encompass specific modes of behaviour that can guide consumers' decisions to make ecological purchases (Vermeir and Verbeke, 2006). The last dimension is the influence of family/friends that is supposed to favour ecological products. According to a European Commission (2013) study, 80\% of Europeans believe that their close relatives would be in favour of their ecological choice, and these relatives are themselves exposed to a multitude of media or state incentives that can guide their position. Thus, we assume the following:

H3: The construct of "propensity to act" positively influences the purchase intention and purchase of environmentally friendly products.

Validation of these assumptions is important because it justifies the interest in using antecedents to understand buying intentions and behaviours. From the proposed model, it will also be possible to know the importance of these antecedents and their predictive power.

\section{Empirical study}

\subsection{Measure and results of the model}

To test the model, we used a sample of 301 people who live in France. This is an appropriate size considering the model estimation procedure used in this study, namely, the maximum likelihood model. According to Roussel et al. (2002), an ideal size is 200 to 300 individuals. The respondents have varied sociodemographic profiles in terms of gender, age, marital status, economic class and income, as shown in Table 2. The survey data are based on a standardized survey questionnaire that we either distributed directly to the respondents or we invited them to participate in the web-based survey. The questionnaire includes three sections. Section one focuses on the items used to measure the antecedents, the second section analyses the intention of buying and the current purchase behaviour and the last section addresses the sociodemographic questions. 
Table 2. Sociodemographic profiles of the respondents

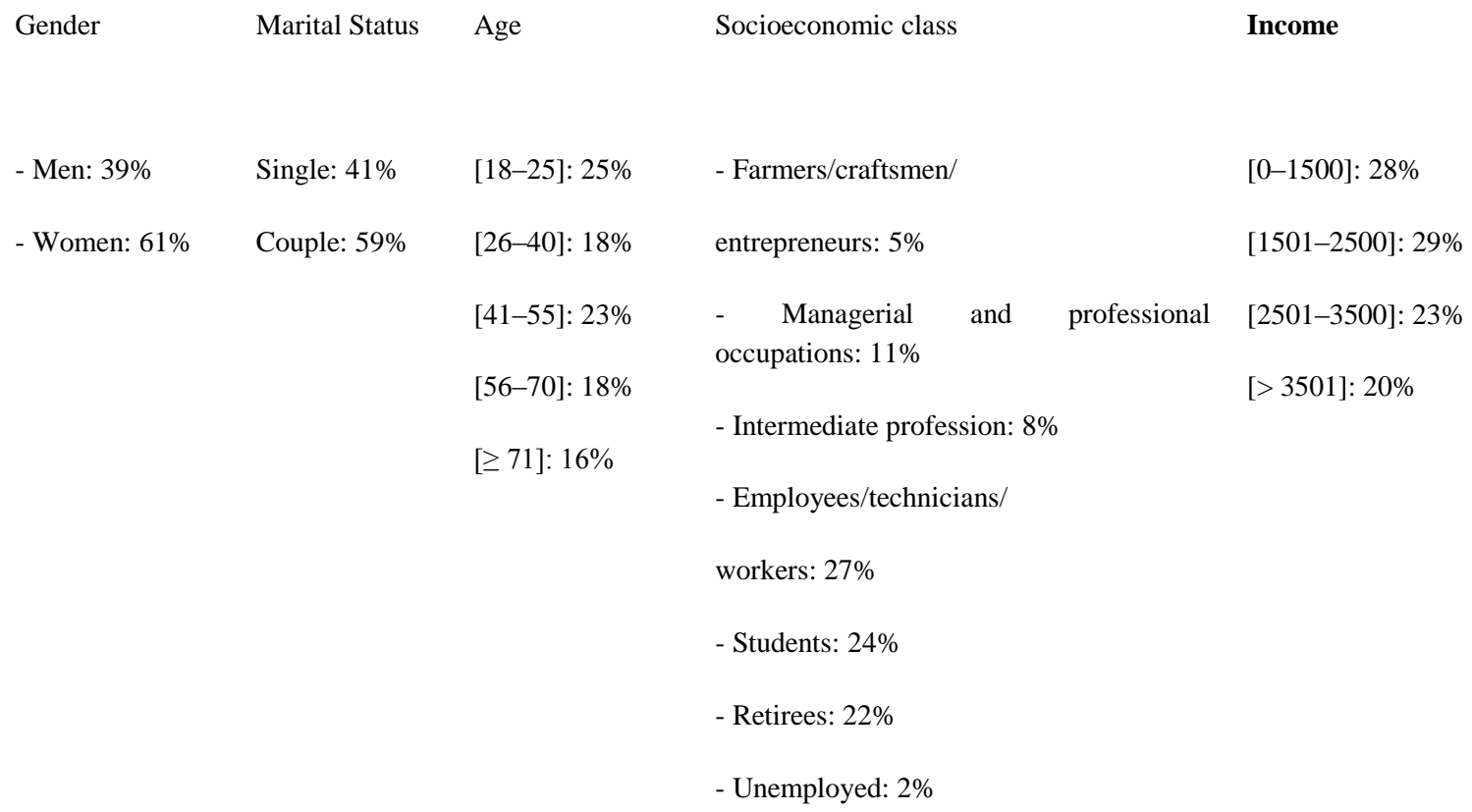

We focused on ecological personal care products, which is a category of products that is increasingly attracting consumers. The global organic personal care market size was estimated at USD 13.13 billion in 2018 (Grand View Research, 2019) with an average growth rate of 9.4\% over the 2019-2025 forecast period. In this study, we adopt a broad definition of ecological personal care products by especially considering their impact on the environment throughout their life cycle (Agence de l'Environnement et de la Maîtrise de l'Énergie -ADEME, 2012). Accordingly, the consumers' overall perception is presented, not the specificities relating to this type of product such as health consciousness (Kim and Chung, 2011).

Both the antecedents and the two endogenous variables were measured by seven-point Likert scales that ranged from 1 (do not agree at all) to 7 (agree entirely). The items used to measure the antecedents and the intent to purchase are existing items that were adapted, while the items to measure the purchase were created for the purposes of this study. These items are shown in Table 3.

Table 3. Scale of measures used in the study

Items used to measure the antecedents (Marde and Verite-Masserot, 2018)

Items adapted for the product used in this study: ecological personal care products (Scale of measure with 7 modalities that range from $1=$ Strongly disagree to $7=$ Strongly agree)

\section{Price: Cronbach's alpha: 0.74}

- $\quad$ I cannot afford to pay more for $[\ldots]$

- In general, the purchase of [...] is associated with different sorts of problems. For me, the price of [...] is often a problem.

\section{Perceived difficulties: Cronbach's alpha: 0.66}

- $\quad$ In stores, I think that the [...] is not showcased enough.

- $\quad$ The $[\ldots]$ are not promoted enough (by advertising).

\section{Buying habits: Cronbach's alpha: 0.83}

- $\quad$ I do not purchase the ecological [...] because I was used to purchasing the non-ecological [...].

- $\quad$ I do not purchase the [...] because I am not used to it. 
- $\quad$ I do not purchase the $[\ldots]$ because it is not easy to change my habits.

Available information: Cronbach's alpha: 0.75

- In general, the purchase of [...] is associated with different sorts of problems. For me, the lack of information about the $[\ldots]$ is often a problem.

- $\quad$ I think we are not very well informed on [...].

- $\quad$ I do not think that there is not enough of an explanation about what the $[\ldots]$ are.

\section{Confidence: Cronbach's alpha: 0.80}

- $\quad$ The $[\ldots]$ are safe.

- $\quad$ I have confidence in the quality of the $[\ldots]$.

- $\quad$ I have no confidence in the $[\ldots] .(\mathrm{R})$

- $\quad$ I run no risk in buying the [...].

\section{Loyalty: Cronbach's alpha: 0.89}

- Usually, I buy the [...].

- $\quad$ Next, time that I buy [...], I will buy only those that are ecological.

- I am loyal to the [...].

- $\quad$ During my recent purchases, I've always bought [...].

\section{Perceived consumer effectiveness: Cronbach's alpha: 0.78}

- $\quad$ Each consumer's behaviour can have a positive effect on society by purchasing [...] sold by socially responsible companies.

- $\quad$ I can protect the environment by buying [...] that are friendly to the environment.

\section{Environmental concern: Cronbach's alpha: 0.87}

- $\quad$ I am very concerned about environmental problems in general.

- $\quad$ I would describe myself as a person fighting on behalf of the environment.

- I I am extremely worried about the state of the global environment and what it will mean for my future.

Social influence: Cronbach's alpha: 0.91

- $\quad$ People who are important to me think I should buy [...].

- $\quad$ My family thinks I should buy [...].

- $\quad$ My friends think I should buy [...].

- $\quad$ People who influence my buying behaviour think I should buy [...].

Values: Cronbach's alpha: $\mathbf{0 . 6 3}$

- $\quad$ Buying [...] instead of conventional products would feel like the morally right thing to do.

- $\quad$ Buying [...] instead of conventional products would make me feel like a better person.

Items used to measure the intention to purchase - Adapted version (Ajzen et al., 2011) and the purchase

Intention to purchase - Cronbach's alpha: 0.93 (Scale with 7 modalities that range from $1=$ Strongly disagree to 7 $=$ Strongly agree)

- $\quad$ I intend to buy $[\ldots]$ soon

- $\quad$ I expect I will buy [...] soon

- $\quad$ I am planning to buy [...] soon

- $\quad$ I am likely to buy [...] soon

- I will probably buy [...] soon

- I have decided to buy [...] soon

Purchase - Cronbach's alpha for this scale is $\mathbf{0 . 8 7}$ 
- $\quad$ How often do you buy [...]? Never (1) (2) (3) (4) (5) (6) (7) Always

- On all your purchases, purchases of ecological fruits and vegetables represent a share: Not at all important (1) (2) (3) (4) (5) (6) (7) Very important

- Of all your personal care products purchases, purchases of ecological personal care products represent a share: Not at all important (1) (2) (3) (4) (5) (6) (7) Very important

- $\quad$ On average, how many ecological personal care products do you buy per week?

- On average, how much money do you spend on ecological personal care products per week?

The different measurement scales provide satisfactory results in terms of reliability and convergent and discriminant validity. To measure the internal consistency of the scales, we used the Cronbach's alpha. The values of the coefficients are near or greater than 0.70 (Table 3), which shows that the scales are reliable. To deepen this first analysis, we used two measurement indicators. First, (1) the rhô of Jöreskog evaluates the reliability of the internal coherence of each scale through a measure of the factorial contributions of the items. The calculations indicate a value greater than 0.70 for each construct, which is an acceptable result (Fornell and Larcker, 1981). There is an exception for the measurement scale of values that has a value of 0.68 , but it remains close to 0.70 . The second indicator is (2) the rho of convergent validity, which represents the percentage of variance that is shared between each factor and its indicators. The explained variance levels must be greater than 50\%, which is the case for all variables in this study. Discriminant validity is the extent to which the measures of two or more different constructs are distinct (Bagozzi et al., 1991; Peter, 1981). Discriminant validity can be obtained when the average variance extracted exceeds the square of the correlation between the latent variable studied and the other dimensions of the measurement model (Fornell and Larcker, 1981). We note that this condition is checked for all constructs (Table 4).

Table 4. Reliability and convergent/discriminant validity of the dimensions

\begin{tabular}{|c|c|c|c|}
\hline & $\begin{array}{l}\text { Reliability (Rhô } \\
\text { of Jöreskog) }\end{array}$ & $\begin{array}{l}\text { Convergent } \\
\text { validity (AVE) }\end{array}$ & Discriminant validity \\
\hline Price & 0.78 & 0.64 & \multirow{4}{*}{$\begin{array}{l}\text { - Price/Perceived difficulties } \\
\Phi^{2}=0.06^{2} \Rightarrow 0.0036<0.64-0.56 \\
\text { - Price/Buying habits } \\
\Phi^{2}=0.32^{2} \Rightarrow 0.1024<0.64-0.7 \\
\text { - Price/Available information } \\
\Phi^{2}=0.37^{2} \Rightarrow 0.1369<0.64-0.56 \\
\text { - Perceived difficulties/Buying habits } \\
\Phi^{2}=-0.01^{2} \Rightarrow-0.0001<0.56-0.7 \\
\text { - Perceived difficulties/Available information } \\
\Phi^{2}=0.78^{2} \Rightarrow 0.61>0.56 \text { - } 0.56 \\
\text { - Buying habits/Available information } \\
\Phi^{2}=0.11^{2} \Rightarrow 0.0121<0.7-0.56\end{array}$} \\
\hline Perceived difficulties & 0.71 & 0.56 & \\
\hline Buying habits & 0.87 & 0.7 & \\
\hline Available information & 0.79 & 0.56 & \\
\hline Confidence: & 0.83 & 0.56 & \multirow[t]{2}{*}{$\begin{array}{l}\text { Confidence/Loyalty } \\
\Phi^{2}=0.61^{2} \Rightarrow 0.3721<0.56-0.74\end{array}$} \\
\hline Loyalty: & 0.92 & 0.74 & \\
\hline $\begin{array}{l}\text { PCE) Perceived } \\
\text { consumer effectiveness }\end{array}$ & 0.83 & 0.72 & \multirow{4}{*}{$\begin{array}{l}\text { - PCE/Concern } \\
\Phi^{2}=0.71^{2} \Rightarrow 0.5041<0.72-0.76 \\
\text { - PCE/Social influence } \\
\Phi^{2}=0.35^{2} \Rightarrow 0.1225<0.72-0.84 \\
\text { - PCE/Values } \\
\Phi^{2}=0.67^{2} \Rightarrow 0.4489<0.72-0.51 \\
\text { - Concern/Social influence } \\
\Phi^{2}=0.52^{2} \Rightarrow 0.2704<0.76-0.84 \\
\text { - Concern/Values } \\
\Phi^{2}=0.44^{2} \Rightarrow 0.1936<0.76-0.51 \\
\text { - Social influence/Values } \\
\Phi^{2}=0.55^{2} \Rightarrow 0.3025<0.84-0.51\end{array}$} \\
\hline Concern & 0.90 & 0.76 & \\
\hline Social influence & 0.90 & 0.84 & \\
\hline Values & 0.68 & 0.51 & \\
\hline Purchase intention & 0.98 & 0.90 & \\
\hline Purchase & 0.94 & 0.75 & \\
\hline
\end{tabular}

The structural equation model (see Annex 1) links the 10 antecedents (lambda- $\lambda$ ) grouped in three constructs (ksi- $\xi$ ) to the two variables that can serve as levers of action, specifically, the intention to purchase and the current purchase (eta$\eta$ ). The results are provided by Lisrel software (Jöreskog and Sörbom, 1993). It can be seen that the indicators for measuring the overall model are satisfactory. The model fit indicators meet the required threshold of 0.8/0.9 (Hu and 
Bentler, 1999; Pedhazur and Schmelkin, 1991). Thus, the value of the goodness-of-fit index (GFI) is 0.96, the value for the adjusted goodness-of-fit index (AGFI) is 0.95 and the comparative fit index (CFI) has a value of 1 . The residual measurement is also acceptable because the standardized root mean square residual (SRMR) is 0.047, which is well below the threshold of 0.08 (Hu and Bentler, 1999), and the value of the root mean square error of approximation (RSMEA) is zero.

The fit statistics of the model are good; therefore, it is necessary to analyse the relations between the exogenous variables (ksi- $\xi$ ) and the endogenous variables (eta- $\eta$ ) to verify the three hypotheses.

The results show that the barrier to purchase is mainly represented by the "buying habits" dimension. The lambda value $(\lambda)$ that measures the strength of this relationship is 0.62 . This is also the case for the "available information" $(\lambda=0.43)$ and "price" $(\lambda=0.34)$ dimensions. In contrast, the "perceived difficulties" dimension is less representative $(\lambda=0.18)$. Regarding the influence of this "barrier to purchase" construct on the endogenous variables, we note that it is strong and negative for both the purchasing intention, with the gamma value $(\gamma)$ being equal to -0.45 , and especially the purchase, with $\gamma=-0.85$. These results reflect reality, given that the purchase variable was measured by the current purchase indicators such as the quantity actually purchased or the budget spent. The existence of these barriers prevents the current purchase of environmentally friendly products. This is also true for future purchases because these barriers negatively influence purchase intention. Thus, given these conclusions, hypothesis 1 cannot be rejected: the barriers to purchase have a negative impact on both the purchase intention and the purchase of environmentally friendly products.

The construct "relations with the product" comprises the two dimensions of "confidence" and "loyalty", which have $(\lambda)$ values equal to 0.70 and 0.39 , respectively. This construct acts positively on the intention to purchase and on the purchase. The $(\gamma)$ values that measure the intensity of the relationship between the exogenous and endogenous variables are limited but positive and are close to 0.10 . The relationship is more important for the purchase variable $(\gamma=0.13)$. Thus, this construct "relations with the product" represented by the positive feelings of the consumer towards the product fosters its current purchase. This is also the case for future purchases because its effect on purchase intention is also positive $(\gamma=0.10)$. Therefore, hypothesis 2 is accepted, and the construct of the relations with the product positively influences the intention to purchase and the purchase of environmentally friendly products.

Concerning the "propensity to act" construct, all of its indicators show good results because the values $(\lambda)$ related to them are close to or greater than 0.50 . The values of lambda are equal to 0.60 for PCE, 0.50 for the "concern" variable, 0.39 for "social influence" and 0.36 for "values". However, in contrast to the other two constructs, the statistics associated with the two endogenous variables do not show the same trend. The influence is positive and significant for the purchase intention $(\gamma=0.46)$, but it is very low for the purchase $(\gamma=0.06)$. This result makes it possible to validate hypothesis 3 but implies questions. Thus, the "propensity to act" construct positively influences the intention to purchase but moderately influences the purchase of environmentally friendly products.

Although the results presented are interesting, they do not necessarily correspond to what would be expected in the field of ecological consumption, especially concerning the "propensity to act" construct. In the next section, we attempt to better understand these results.

\subsection{Discussion and implications of the results}

The present study shows the important role of the antecedents of environmentally friendly consumption in purchase intention and buying behaviour. A detailed analysis of the results allows us to extract useful information for marketing actions. Important information for managers concerns the "barriers to purchase". We find that price, the information available and the buying habits for conventional products remain important barriers. The "perceived difficulties" dimension has a lower weight (0.18). This two-item dimension essentially refers to the promotion of products. The two items used are

"In stores, I think that the [...] is not showcased enough" and "The [...] are not promoted enough (by advertising)". Regarding ecological or green products, most consumers are quite positive in their response to advertisements (Purohit, 2012; Sravanthi and Amruth Prasad Reddy, 2019; Thorson et al., 1995). According to a 2016 study by Agence BIO in France, $65 \%$ of the respondents consider that they have sufficient information about green products at the point of sale. This result is consistent with the findings of Leonidou et al. (2011), who by analysing 473 international green advertisements during the 1988-2007 period, observe an increase in the amount of details in green advertisements over time. Therefore, it is likely that the actions taken by companies in this field have been noticed by consumers so that the lack of promotion is currently no longer a major obstacle for them. Furthermore, it is not as difficult for consumers to access these types of products due to their increased availability and a growing green market. These results corroborate the statistical data published by the Commissariat Général au Développement Durable (2016) that show that in France, 
for example, the most important barriers are price, the information available and, to a lesser extent, the promotion of these products. According to the study, people have an incentive to buy environmentally friendly products if it is certain that the products are not more expensive $(41 \%)$ and that the consumers are better informed $(21 \%)$. The reasons related to the availability of these products and their promotion have become much less important (14\%), whereas this percentage was $25 \%$ in 2010.

Another important result concerns the influence of the "barriers to purchase" on future purchase intention. It is justified that the existence of these barriers prevents the current purchase, but its negative effect on future purchases is of concern because it means that the awareness of environmental problems, coupled with a willingness to contribute, are challenged by these barriers. In this area, the statistics are not encouraging: although $75 \%$ of Europeans say that they are ready to buy ecological products, only 17\% have actually purchased them (European Commission, 2014). According to Kaiser (2006), when behaviour depends more on circumstances that are external to a person (a fixed price or availability, for example), the behaviour is less intentionally controllable. These barriers could therefore be strong reasons for non-purchase. Consequently, according to our results, the challenge is clear: it is important to change the purchasing habits of consumers in favour of environmentally friendly products. This goal seems to be entirely possible, provided that the barriers are removed, that is, that consumers are better informed and that these products respect their environmental promises, are available and featured on shelves, and are available at the right price.

The results that relate to the "relations with the product" construct show a positive but relatively small influence on the intention to purchase and purchase of ecological products. Although having confidence in a product does not necessarily lead to a consumer buying it, the results concerning the loyalty variable are more difficult to explain. According to several studies, product loyalty leads a consumer to purchase a product (Lewis, 2004; Meyer-Waarden, 2008), which does not appear to be evident in the present model. It is possible that many consumers, although faithful to this type of product, have a low frequency of purchase and a dedicated budget. Moreover, it is likely that other variables that are more constraining to the consumer will hinder the purchase and reduce the impact of loyalty.

The last significant result of this study concerns the relationship between the "propensity to act" construct and the "purchase" variable, which is positive but low $(\gamma=0.06)$. This unexpected result may nevertheless be justified because the concept of "propensity to act" has been measured by general items that relate to an individual's interest in environmental problems. The propensity to act is a predisposition to action in favour of the environment and is not limited to the specific predisposition to buy green products. It is therefore likely that other actions aimed at protecting the environment, such as waste sorting or elimination, are better accepted by individuals than the mobilization of their buying power. We should also note the phenomenon of resistance, which is manifested by opposition to perceived forms of pressure or influence (Roux, 2007). In this domain, the ecological discourse of the companies that are part of a "commercial logic" (Peñaloza and Price, 1993) can be perceived as manipulative and thus lead to a resistance to purchase. For some consumers, the ecological implication of companies might be seen more as a pretext for a sale or as a way of concealing an economy that does not benefit customers (Monnot and Reniou, 2013), which can cause them to refuse to purchase or to impose important requirements. Therefore, promoting buying behaviours, which are admittedly ecological, to contribute to the problems of the environment may seem to be contradictory if one considers that being ecologically aware requires, in particular, a reduction in consumption. 


\section{Appendix}

\section{A1. The theoretical global model}

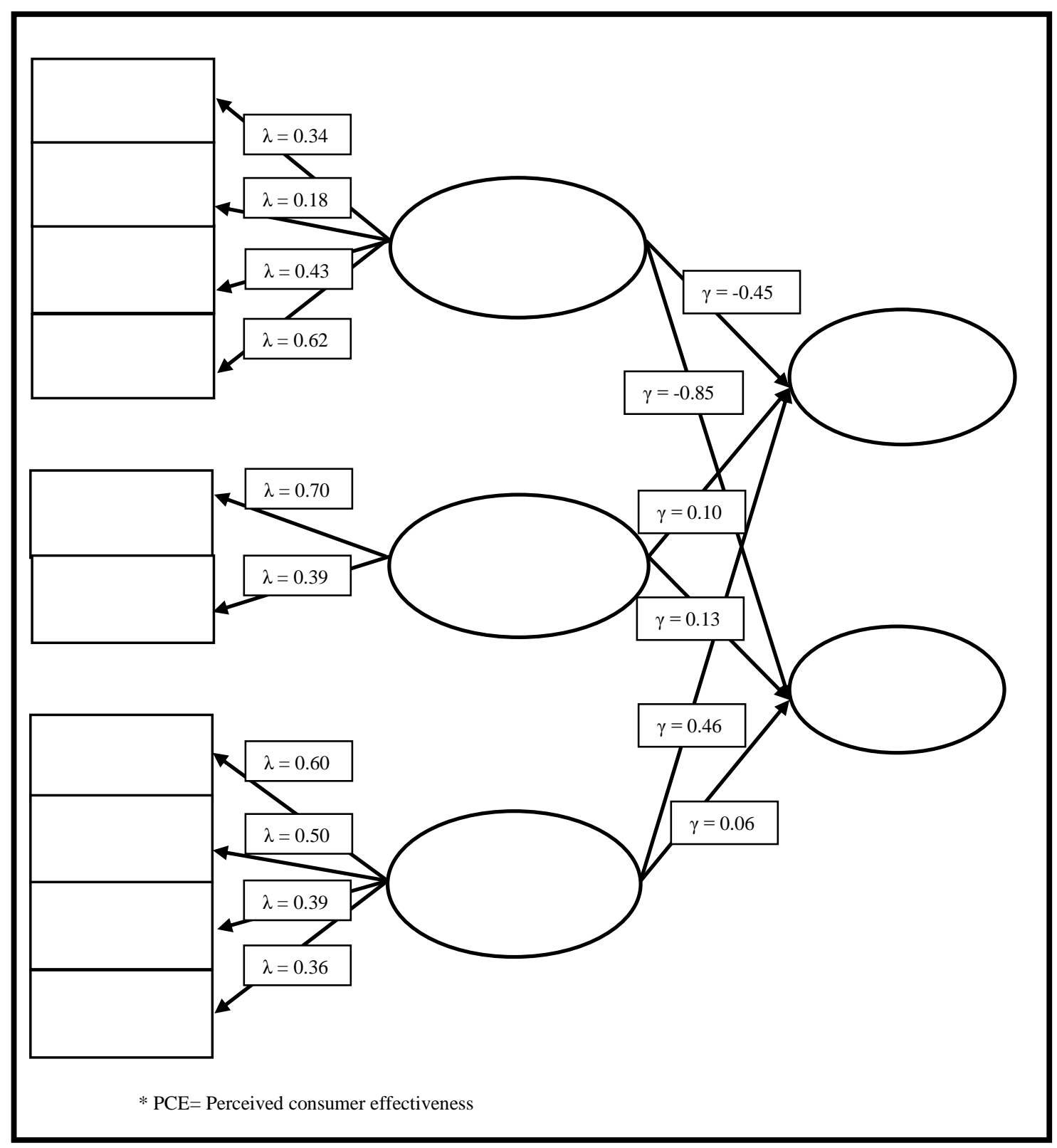

\section{Conclusion}

This study emphasised the antecedents of ecological consumption and measured its impact on purchasing and purchasing intent. The results offer an additional element to academic research because it is now possible to understand the overall ecological purchasing process that goes from the antecedents to the final act of purchase. In the environmental field, different types of behaviours can be selected, and buying green products is among these behaviours (Gordon-Wilson and Modi, 2015). In this way, we know that "barriers" slow purchase intent and buying, while a positive "relation with the product" favours purchase intent and buying. The "propensity to act" in favour of the environment appears to not favour the current purchase but is more favourable for future purchases. For a company, this information is useful for establishing appropriate actions, especially because it is possible to know precisely which antecedents to focus on, as each construct comprises several antecedents. At the company-specific level, the measurement scale of the antecedents can be used to create client typologies depending on the product being studied.

However, this research has its limitations. The first methodological limitation concerns the results of the structural equation model, which, although acceptable, should be tested again to verify its stability, especially by using other 
types of ecological products and by increasing the size of the sample. Our analyses are based on the measures of selfreported intentions and behaviours, which is a methodological limit that does not allow us to address the problem of social desirability bias. We know that this bias is pronounced in studies with ethical considerations (Carrigan and Attalla, 2001), such as studies of ecological consumption. Therefore, experimentation, based on direct observation in the store or indirectly via, for example, an analysis of purchases recorded on consumer loyalty cards, would make it possible to address this bias.

Finally, it would be useful to analyse the possible impacts of external variables on the results because the approach taken in this study assumes that consumers, public authorities and companies are all mobilized for the environmental cause, which is probably not always the case in developed countries. Differences in commitment among parties and countries could vary the results.

\section{References}

Agence BIO. (2016). Baromètre de consommation et de perception des produits biologiques en France, available : http://www.agencebio.org/sites/default/files/upload/documents/4_Chiffres/BarometreConso/rapport_agence_bi ocsa_2016vf.pdf.

Agence de l'Environnement et de la Maîtrise de l'Énergie -ADEME. (2012), Consommer mieux,available : https://preval.fr/wp/wp-content/uploads/2012/07/guide_ademe_consommer_mieux.pdf.

Ajzen, I. (1987). Attitudes, traits, and actions: dispositional prediction of behaviour in personality and social psychology.Advances in Experimental Social Psychology,20, 1-63.

Ajzen, I. (1991). The theory of planned behavior. Organizational Behavior and Human Decision Processes, 50(2), 179-211. https://doi.org/10.1016/0749-5978(91)90020-T

Ajzen, I., Joyce, N., Sheikh, S. \& Cote, N. G. (2011). Knowledge and the prediction of behavior: The role of information accuracy in the theory of planned behavior.Basic and Applied Social Psychology, 33(2), 101117.https://doi.org/10.1080/01973533.2011.568834

Albayrak, T., Caber, M., Moutinho, L., \& Herstein, R. (2011). The influence of skepticism on green purchase behaviour. International Journal of Business and Social Science, 2(13),

Andorfer, V. A., \& Liebe, U. (2012). Research on fair trade consumption: A review. Journal of Business Ethics, 106(4), 415-435. https://doi.org/10.1007/s10551-011-1008-5.

Bagozzi, R.P., Yi, Y. \&Phillips, L.W. (1991), Assessing construct validity in organizational research.Administrative Science Quarterly,36(3), pp. 421-458.http://dx.doi.org/10.2307/2393203

Balderjahn, I. (1988). Personality variables and environmental attitudes as predictors of ecologically responsible consumption patterns.Journal of Business Research,17(1), 51-56.https://doi.org/10.1016/0148-2963(88)900227

Barbarossa, C. \& De Pelsmacker, P. (2016). Positive and negative antecedents of purchasing eco-friendly products: a comparison between green and non-green consumers.Journal of Business Ethics,134 (2), 229247.https://doi.org/10.1007/s10551-014-2425-z

Basha, M.B. \& Lal, D. (2019). Indian consumers' attitudes towards purchasing organically produced foods: an empirical study.Journal of Cleaner Production,215, 99-111.doi: 10.1016/j.jclepro.2018.12.098

Bozzo, C., Merunka, D. \& Moulins, J.-L. (2003). Fidélité et comportement d'achat: ne pas se fier aux apparences.Décisions Marketing,32, 9-17.

Carrigan, M. \& Attalla, A. (2001).The myth of the ethical consumer - do ethics matter in purchase behaviour? Journal of Consumer Marketing,18(7), 560-578.DOI: 10.1108/07363760110410263

Carrington, M.J., Neville, B.A. \& Whitwell, G.J. (2010). Why ethical consumers don't walk their talk: towards a framework for understanding the gap between the ethical purchase intentions and actual buying behaviour of ethically minded consumers.Journal of Business Ethics,97(1), 139-158.https://doi.org/10.1007/s10551-0100501-6

Chen, M.-F., \& Tung, P.-J. (2014). Developing an extended Theory of Planned Behavior model to predict consumers' intention to visit green hotels. International Journal of Hospitality Management, 36, 221-230. https://doi.org/10.1016/j.ijhm.2013.09.006

Commissariat Général au Développement Durable (2016), Opinions et Pratiques Environnementales des Français en 2015, Chiffres \& Statistiques.No. 750, available:https://www.statistiques.developpementdurable.gouv.fr/sites/default/files/2018-10/chiffres-stats750-opinions-pratiques-environnementales-2015avril2016-b_0.pdf. 
Diamantopoulos, A., Schlegelmilch, B.B., Sinkovics, R.R. \& Bohlen, G.M. (2003). Can socio-demographics still play a role in profiling green consumers? A review of the evidence and an empirical investigation.Journal of Business Research. 56(6), 465-480.https://doi.org/10.1016/S0148-2963(01)00241-7

Ellen, P.S., Wiener, J.L. \& Cobb-Walgren, C. (1991). The role of perceived consumer effectiveness in motivating environmentally conscious behaviors. Journal of Public Policy \& Marketing,10(2), 102-117. https://doi.org/10.1177/074391569101000206

European Commission. (2013), Attitudes of Europeans toward Building the Single Market for Green Products, Report, Flash Eurobarometer 367, TNS Political \& Social, Brussels.

European Commission. (2014), Attitudes of European Citizens towards the Environment, Report, Special Eurobarometer 416, TNS Opinion \& Social, Brussels.

Fornell, C. \& Larcker, D.F. (1981). Structural equation models with unobservable variables and measurement error: algebra and statistics.Journal of Marketing Research,18(3), 382-388. https://doi.org/10.1177/002224378101800313

Ghazali, E., Soon, P.C., Mutum, D.S. \& Nguyen, B. (2017). Health and cosmetics: investigating consumers' values for buying organic personal care products.Journal of Retailing and Consumer Services,39, 154-163. https://doi.org/10.1016/j.jretconser.2017.08.002

Giger, J.-C. (2008). Examen critique du caractère prédictif, causal et falsifiable de deux théories de la relation attitudecomportement : la théorie de l'action raisonnée et la théorie du comportement planifié.L'Année psychologique,108(1), 107-131.www.persee.fr/doc/psy_0003-5033_2008_num_108_1_30963

Gilg, A., Barr, S. \& Ford, N. (2005). Green consumption or sustainable lifestyles? Identifying the sustainable consumer.Futures,37(6), 481-504.https://doi.org/10.1016/j.futures.2004.10.016

Gleim, M.R., Smith, J.S., Andrews, D. \& Cronin, J.J. (2013). Against the green: a multi-method examination of the barriers to green consumption.Journal of Retailing,89(1), 44-61.https://doi.org/10.1016/j.jretai.2012.10.001

Golob, U., Koklic, M.K., Podnar, K. \& Zabkar, V. (2018). The role of environmentally conscious purchase behaviour and green scepticism in organic food consumption.British Food Journal,120(10), 24112424.https://doi.org/10.1108/BFJ-08-2017-0457

Gordon-Wilson, S. \& Modi, P. (2015). Personality and older consumers' green behaviour in the UK.Futures, 71, 110.https://doi.org/10.1016/j.futures.2015.05.002

Grand View Research. (2019). Organic personal care market size, share \& trends analysis report by application (cosmetics, skin, oral, hair care), by region, and segment forecasts, 2019 - 2025.Available: http://www.grandviewresearch.com/industry-analysis/organic-personal-care-market.

Grunert, S.C. \& Juhl, H.J. (1995). Values, environmental attitudes, and buying of organic foods.Journal of Economic Psychology,16 (1), 39-62.https://doi.org/10.1016/0167-4870(94)00034-8

Hassan, L.M., Shiu, E. \& Shaw, D. (2016). Who says there is an intention-behaviour gap? Assessing the empirical evidence of an intention-behaviour gap in ethical consumption. Journal of Business Ethics,136(2), 219236.https://doi.org/10.1007/s10551-014-2440-0

Hsu, C.-L., Chang, C.-Y. \& Yansritakul, C. (2017). Exploring purchase intention of green skincare products using the theory of planned behavior: testing the moderating effects of country of origin and price sensitivity.Journal of Retailing and Consumer Services,34,145-152.https://doi.org/10.1016/j.jretconser.2016.10.006

Hu, L.T. \& Bentler, P.M. (1999). Cutoff criteria for fit indexes in covariance structure analysis: conventional criteria versus new alternatives. Structural Equation Modeling: A Multidisciplinary Journal,6(1), 155.https://doi.org/10.1080/10705519909540118

Isenhour, C. (2010). On conflicted Swedish consumers, the effort to stop shopping and neoliberal environmental governance.Journal of Consumer Behaviour, 9 (6), 454-469.https://doi.org/10.1002/cb.336

Jöreskog, K.G. and Sörbom, D. (1993), LISREL 8: Structural Equation Modeling with the SIMPLIS Command Language, Erlbaum, Hillsdale, NJ.

Kaiser, F.G. (2006). A moral extension of the theory of planned behavior: norms and anticipated feelings of regret in conservationism.Personality and Individual Differences,41(1), 71-81. https://doi.org/10.1016/j.paid.2005.11.028

Kim, H.Y. \& Chung, J.-E. (2011). Consumer purchase intention for organic personal care products. Journal of Consumer Marketing,28(1), 40-47.https://doi.org/10.1108/07363761111101930

Kim, Y. and Choi, S.M. (2005). Antecedents of green purchase behavior: an examination of collectivism, environmental concern, and PCE", Advances in Consumer Research,32(1), 592-599.

Kinnear, T.C., Taylor, J.R. \& Ahmed, S.A. (1974). Ecologically concerned consumers: who are they?Journal of Marketing, 38(2), 20-24.https://doi.org/10.1177/002224297403800205 
Laurent, G. \& Kapferer, J.-N. (1985). Measuring consumer involvement profiles. Journal of Marketing Research,22 (1), 41-53.https://doi.org/10.1177/002224378502200104

Leonidou, L.C., Leonidou, C.N., Palihawadana, D. \&Hultman, M. (2011). Evaluating the green advertising practices of international firms: a trend analysis. International Marketing Review,28(1), 6-33. https://doi.org/10.1108/02651331111107080

Lewis, M. (2004). The influence of loyalty programs and short-term promotions on customer retention.Journal of Marketing Research,41(3), 281-292.https://doi.org/10.1509/jmkr.41.3.281.35986

Maniatis, P. (2016). Investigating factors influencing consumer decision-making while choosing green products. Journal of Cleaner Production,132, 215-228.https://doi.org/10.1016/j.jclepro.2015.02.067

Marde, S. \& Verite-Masserot, C. (2018). Antecedents of green consumption: a scale of measure. Journal of Consumer Marketing,35(4), 414-425.https://doi.org/10.1108/JCM-08-2016-1927

Meyer-Waarden, L. (2008). The influence of loyalty programme membership on customer purchase behaviour.European Journal of Marketing, 42 (1/2), 87-114.https://doi.org/10.1108/03090560810840925

Monnot, E. and Reniou, F. (2013), "“Ras le bol d'entendre parler d'écologie!":comprendre la contestation des discours écologiques parles consommateurs", Décisions Marketing, Vol. 71 No. 71, pp. 93-109. http://dx.doi.org/10.7193/DM.071.93.109

Moser, A.K. (2015). Thinking green, buying green? Drivers of pro-environmental purchasing behavior. Journal of Consumer Marketing, 32(3), 167-175.https://doi.org/10.1108/JCM-10-2014-1179

Mostafa, M.M. (2007). A hierarchical analysis of the green consciousness of the Egyptian consumer. Psychology and Marketing,24(5), 445-473.https://doi.org/10.1002/mar.20168

189-197

Nuttavuthisit, K. \& Thøgersen, J. (2017). The importance of consumer trust for the emergence of a market for green products: the case of organic food. Journal of Business Ethics, 140 (2), 323-337. https://doi.org/10.1007/s10551-015-2690-5

Ogden, J. (2003). Some problems with social cognition models: A pragmatic and conceptual analysis. Health Psychology, 22(4), 424-428. https://doi.org/10.1037/0278-6133.22.4.424

Ostrom, T.M. (1969). The relationship between the affective, behavioral, and cognitive components of attitude.Journal of Experimental Social Psychology, 5 (1), 12-30.https://doi.org/10.1016/0022-1031(69)90003-1

Pagiaslis, A. \& Krontalis, A.K. (2014). Green consumption behavior antecedents: environmental concern, knowledge, and beliefs.Psychology \& Marketing, 31(5), 335-48.https://doi.org/10.1002/mar.20698

Paul, J., Modi, A. \& Patel, J. (2016). Predicting green product consumption using theory of planned behavior and reasoned action.Journal of Retailing and Consumer Services,29, 123-134. https://doi.org/10.1016/j.jretconser.2015.11.006

Paul, J. \&Rana, J. (2012). Consumer behavior and purchase intention for organic food. Journal of Consumer Marketing, 29(6), 412-422.https://doi.org/10.1108/07363761211259223

Pedhazur, E.J. and Schmelkin, L.P. (1991), Measurement, Design, and Analysis: An Integrated Approach, Lawrence Erlbaum Associates, Hillsdale, NJ.

Peñaloza, L. and Price, L. (1993), "Consumer resistance: a conceptual overview", inMcAlister, L. and Rothschild, M. (Eds.), Advances in Consumer Research, Association for Consumer Research, Provo, UT, 123-128.

Peter, J.P. (1981). Construct validity: a review of basic issues and marketing practices.Journal of Marketing Research,18(2), 133-145.https://doi.org/10.1177/002224378101800201

Pickett-Baker, J. \& Ozaki, R. (2008). Pro-environmental products: marketing influence on consumer purchase decision.Journal of Consumer Marketing,25(5), 281-293.https://doi.org/10.1108/07363760810890516

Plous, S. (1993), The Psychology of Decision Making, McGraw-Hill, New York.

Prothero, A., Dobscha, S., Freund, J., Kilbourne, W.E., Luchs, M.G., Ozanne, L.K. \& Thøgersen, J. (2011). Sustainable consumption: opportunities for consumer research and public policy. Journal of Public Policy \& Marketing,30(1), 31-38.https://doi.org/10.1509/jppm.30.1.31

Purohit, H. (2012), "Product positioning and consumer attitude towards eco-friendly labeling and advertisement: an analytical study", Journal of Management Research, Vol. 12 No. 3, pp. 153-162.

Robinson, R. \& Smith, C. (2002). Psychosocial and demographic variables associated with consumer intention to purchase sustainably produced foods as defined by the midwest food alliance.Journal of Nutrition Education and Behavior, 34(6), 316-325.https://doi.org/10.1016/S1499-4046(06)60114-0

Rokeach, M. (1973), The Nature of Human Values, Free Press, New York.

Rosenberg, M.J. and Hovland, C.I. (1960), "Cognitive, affective and behavioral components of attitudes", inHovland, C.I. and Rosenberg, M.J. (Eds.), Attitude Organization and Change, Yale University Press, New Haven, pp. 112-163. 
Roussel, P., Durrieu, F., Campoy, E. and El Akremi, A. (2002), Méthodes d'Équations Structurelles: Recherche et Applications en Gestion, Économica, Paris.

Roux, D. (2007).vLa resistance du consommateur: proposition d'un cadre d'analyse.Recherche et Applications en Marketing,22(4), 59-80.https://doi.org/10.1177/076737010702200403

Sravanthi, MBS \& Amruth Prasad Reddy, A (2019). Green Marketing Dynamics by Consumers towards the Awareness, Purchase andPromotion of Green Products. International Journal of Business and Social Science, 10(2).http://dx.doi.org/10.30845/ijbss

Stern, P.C. (1999). Information, incentives, and proenvironmental consumer behavior.Journal of Consumer Policy,22 (4), 461-478.https://doi.org/10.1023/A:1006211709570

Straughan, R.D. \&Roberts, J.A. (1999). Environmental segmentation alternatives: a look at green consumer behavior in the new millennium.Journal of Consumer Marketing,16(6), 558-575. https://doi.org/10.1108/07363769910297506

Thorson, E., Page, T. \&Moore, J. (1995), "Consumer response to four categories of "green" television commercials", inKardes, F.R. and Sujan, M. (Eds.), Advances in Consumer Research, Association for Consumer Research, Provo, UT, pp. 243-250.

Van Doorn, J. \& Verhoef, P.C. (2015). Drivers of and barriers to organic purchase behavior. Journal of Retailing,91(3), 436-450.https://doi.org/10.1016/j.jretai.2015.02.003

Vermeir, I. \& Verbeke, W. (2006). Sustainable food consumption: exploring the consumer "attitude - behavioral intention" gap. Journal of Agricultural and Environmental Ethics, 19 (2), 169-194. https://doi.org/10.1007/s10806-005-5485-3

Vermeir, I. \& Verbeke, W. (2008). Sustainable food consumption among young adults in Belgium: theory of planned behaviour and the role of confidence and values. Ecological Economics,64(3), 542-553. https://doi.org/10.1016/j.ecolecon.2007.03.007

Wiederhold, M. \& Martinez, L.F. (2018). Ethical consumer behaviour in Germany: the attitude-behaviour gap in the green apparel industry.International Journal of Consumer Studies, 42(4), 419-429. https://doi.org/10.1111/ijcs.12435

Yadav, R. \& Pathak, G.S. (2016). Young consumers' intention towards buying green products in a developing nation: extending the theory of planned behavior. Journal of Cleaner Production,135, 732-739. https://doi.org/10.1016/j.jclepro.2016.06.120 